\title{
PENGARUH JENIS VAKSIN DAN KONSENTRASI VITAMIN C TERHADAP SINTASAN PASCALARVA UDANG WINDU YANG DIPAPAR DENGAN WHITE SPOT SYNDROME VIRUS(WSSV)
}

\author{
Muharijadi Atmomarsono, Muliani, dan Mun Imah Madeali
}

\begin{abstract}
ABSTRAK
Penelitian bertujuan untuk mengetahui pengaruh jenis vaksin dan konsentrasi vitamin C (Vit. C) terhadap sintasan pascalarva udang windu yang terpapar dengan White Spot Syndrome Virus (WSSV). Penelitian dilakukan di Laboratorium Basah Balai Riset Perikanan Budidaya Air Payau, Maros yang terdiri atas beberapa tahap; (1) produksi vaksin WSSV dan vaksin vibrio; (2) Uji LC $\mathrm{L}_{50}$ WSSV; (3) aplikasi vaksin dengan metode perendaman; dan (4) uji papar dengan WSSV. Parameter yang diamati meliputi sintasan pascalarva udang windu dan nilai RPS vaksin. Hasil penelitian menunjukkan bahwa sintasan pascalarva udang windu tertinggi pada perlakuan yang

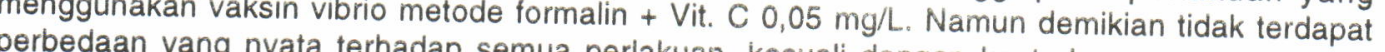
perbedaan yang nyata terhadap semua periakuan, kecuali dengan kontrol penggunaan vaksin RSS tertinggi $(50 \%)$ dit. dan penggunaan vaksin vibrio metode formalin + Vit $C 0,03 \mathrm{mg} / \mathrm{L}$. Nilai RPS tertinggi $(50 \%)$ diperoleh pada perlakuan vaksin vibrio dengan metode formalin + Vit. C 0,05 $\mathrm{mg} / \mathrm{L}$. Hal ini menunjukkan bahwa jenis vaksin vibrio + Vit. C 0,05 mg/L lebih efektif sebagai immunostimulan dibanding dengan jenis vaksin lainnya yang digunakan.
\end{abstract}

$\begin{array}{ll}\text { ABSTRACT: } & \text { Effect of different vaccine and Vit. C concentration on survival rate of tiger } \\ & \text { shrimp postlarvae, challenged with White Spot Syndrome Virus (WSSV). By: } \\ & \text { Muharijadi Atmomarsono, Muliani, and Mun Imah Madeali }\end{array}$

The objective of research is to know the effect of different vaccine and Vit. C concentration on Survival rate of tiger shrimp postlarvae challenged with White Spot Syndrome Virus (WSSV). (RICA), consists of several activities laboratory of Research Institute for Coastal Aquaculture Test for WSSV virus; (3) immersed vacin (1) production of WSSV and Vibrio vaccines; (2) LC50 Test for WSSV virus; (3) immersed vaccine and Vit. C and (4) challenge test with WSSV virus. The parameters observed were survival rate of tiger shrimp postlarvae and RPS of value of vaccine. The results of experiment showed that the highest survival rate was achieved by tiger shrimp postlarvae treated with vibrio vaccine + Vit. C $0.05 \mathrm{mg} / \mathrm{L}$. Statistical analysis showed that the survival rates of tiger shrimp postlarvae were mostly not significantly different within the treatments, vaccine + Vit. C $0.05 \mathrm{mg} / \mathrm{l}$. The highe with control, the use virus vaccine + Vit. C $0.01 \mathrm{mg} / \mathrm{L}$ and vibrio $L$. It is concluded that the vilu vibrio vaccine + Vit. C $0.05 \mathrm{mg} /$ L. It is concluded that the vibrio vaccine + Vit. $C 0.05 \mathrm{mg} / \mathrm{L}$ was the most effective immunostimulant among the vaccines tested in this experiment.

KEYWORDS: Vaccine, vitamin C, tiger shrimp, White Spot Syndrome Virus

\section{PENDAHULUAN}

Berbagai kasus penyakit di tambak telah dilaporkan oleh petani tambak, mulai dari penyakit udang lumutan, udang menyala, insang merah, udang berkepala kuning, sampai pada penyakit udang bintik putih. Demikian halnya di panti benih dilaporkan adanya kasus penyakit udang menyala (berpendar) yang disebabkan oleh Vibrio harveyi yang menyebabkan kematian massal pada larva udang windu. Madeali et al. (1998) melaporkan bahwa ada tiga jenis virus yang telah diidentifikasi menyerang udang di Sulawesi Selatan baik di panti perbenihan maupun di tambak pembesaran yaitu Monodon Baculo Virus (MBV), White Spot Syndrome Virus (WSSV), dan Hepatopancreatic Parvo-like Virus (HPV). Albaladejo et al. (1998) melaporkan bahwa sebanyak 250 ekor sampel udang dari beberapa daerah pertambakan di Filipina, dengan metode Enzym Immunoassay (EIA) dideteksi 41 sampel di antaranya positif terserang Yellow Head Virus (YHV). Di India, sebanyak 630 sampel udang yang terdiri atas pascalarva dan yuwana, 53\% di antaranya positif terserang WSSV (Vaseeharan et al., 2003). Beberapa

Peneliti pada Balai Riset Perikanan Budidaya Air Payau, Maros 
jenis virus (Baculo-like viruses) ditemukan menyerang udang di Taiwan dan Jepang sehingga menurunkan produksi udang di kedua negara tersebut. Di Taiwan misalnya, produksi udang windu menurun dari 90.000 MT pada tahun 1987 menjadi 20.000 MT pada tahun 1989, dan sampai sekarang produksi udang di negara tersebut belum pulih kembali (Maeda, 1999).

WSSV merupakan salah satu jenis virus yang paling banyak menimbulkan kematian udang di tambak (Peng et al., 2001; Li et al., 2003). Menurut Chang et al. (1998), WSSV dapat mengakibatkan mortalitas pada udang windu sebesar $100 \%$ dalam waktu $2-7$ hari. Pada udang yang terserang virus ini secara morfologi terdapat bintik putih.

Berbagai usaha telah dilakukan untuk menanggulangi penyakit udang di Indonesia, di antaranya melalui penggunaan vaksin dan immunostimulan. Menurut Kamiso (1996), vaksin adalah suspensi patogen hidup yang sudah dilemahkan, patogen yang sudah dimatikan, bagian dari patogen atau substrat yang merupakan produk patogen yang bersifat antigenik, immunogenik, dan protektif. Syarat dari suatu vaksin harus bersifat immunogen, artinya harus dapat merangsang dalam pembentukan antibodi yang bertujuan untuk mendapatkan kekebalan secara aktif, di mana antigen tersebut bersama dengan sel limfoid membentuk antibodi (Supriyadi, 1990; Brock et al., 1994 ; Madigan et al., 2000). Selanjutnya Kamiso (1996) menyatakan bahwa vaksinasi adalah proses memasukkan antigen (vaksin) ke dalam tubuh ikan/udang untuk mendapatkan kekebalan spesifik dan non-spesifik sehingga ikan / udang kebal terhadap patogen tertentu. Dari hasil penelitian sebelumnya terlihat bahwa vaksin virus walaupun belum mampu menekan kematian udang, namun dari uji ELISA menunjukkan nilai kerapatan optikal (OD) yang lebih rendah pada benur yang lebih sering divaksin. Penambahan vitamin C pada dosis $0,05 \mathrm{mg} / \mathrm{L}$ yang diberikan setiap 4 hari juga dapat meningkatkan kekebalan benur windu terhadap serangan WSSV.

Pengujian dan pemanfaatan vaksin vibrio dengan penambahan vitamin $\mathrm{C}$ masih perlu dilakukan dan dikaji lebih lanjut. Hal ini dimaksudkan untuk lebih meningkatkan efektivitas penggunaannya dalam meningkatkan ketahanan udang terhadap serangan penyakit. Dengan demikian sintasan larva udang windu dapat ditingkatkan dan pada gilirannya akan menaikkan produksi udang windu.

Penelitian bertujuan untuk mengetahui pengaruh jenis vaksin dan konsentrasi Vitamin C terhadap sintasan larva udang windu yang dipapar dengan virus WSSV.

\section{BAHAN DAN METODE}

\section{Pembuatan Vaksin}

Vaksin (crude vaccine) WSSV dibuat dengan cara mematikan antigen virus dengan formalin (Fryer et al., 1976 dalam Wolf, 1988) yaitu dari sampel udang windu yang secara morfologi mempunyai tanda bintik putih yang disebabkan oleh virus WSSV (Gambar 1). Karapas udang dikerik dan digerus hingga halus, kemudian dihomogenkan, disentrifugasi, dan disaring dengan filter milipore $450 \mathrm{~nm}$. Filtranya (virus) kemudian dimatikan dengan formalin $1 \%$ selama 24 jam pada suhu $4^{\circ} \mathrm{C}$. Kemudian disentrifugasi dan dicuci 3 kali dengan larutan fisiologis ( $\mathrm{NaCl} 0,85 \%$ ). Adapun vaksin bakteri ( $V$. harveyi) dibuat berdasarkan modifikasi dari metode Kamiso (1996) yaitu dari Antigen $(\mathrm{Ag})$ tidak murni sebagai berikut:

1. Seluruh ( $\mathrm{Ag} \mathrm{H}$ atau flagella) dibuat dari kultur murni cair (broth) dimatikan dengan formalin 1\% selama 24 jam pada suhu $4^{\circ} \mathrm{C}$, kemudian dipanen dan dicuci 3 kali dengan 0,85\% larutan garam $\mathrm{NaCl}$ dengan sentrifugasi (> $3.000 \mathrm{rpm}$ selama 20 menit).

2. Ag-O atau LPS yang diperoleh dari kultur murni cair Vibrio dipanaskan pada suhu $100^{\circ} \mathrm{C}$ selama 20 menit. Selanjutnya dipanen dan dicuci 3 kali dengan 0,85\% larutan garam $\mathrm{NaCl}$ dengan sentrifugasi (> 3.000 rpm selama 20 menit).

\section{Uji LC $_{50}$ Virus WSSV terhadap Pascalarva Udang Windu}

Penelitian ini dilakukan pada skala laboratorium dengan menggunakan stoples kaca berkapasitas $3 \mathrm{~L}$ yang masing-masing diisi $2 \mathrm{~L}$ air dengan salinitas 27 28 ppt yang telah disterilkan memakai kaporit dan dinetralkan dengan natrium thiosulfat. Tiap stoples diisi 30 ekor benur windu PL-20 yang sebelumnya telah diaklimatisasikan terhadap suhu dan salinitas air. Untuk uji LC50 WSSV terhadap larva udang windu digunakan 9 tingkatan konsentrasi yaitu; (1) $0 \mathrm{~mL}$ (kontrol); (2) 1,78 mL; (3) 3,1 mL; (4) 5,62 mL; (5) 10 $\mathrm{mL}$; (6) 17,78 mL; (7) 31,62 mL; (8) 56,23 mL; dan (9) $100 \mathrm{~mL}$ per 2 liter air media. Masing-masing konsentrasi diulang tiga kali. Kematian pascalarva udang windu diamati setelah 24 jam perendaman. Penghitungan dosis mematikan $50 \%$ pascalarva udang windu dilakukan menggunakan analisis probit (Steel \& Torrie, 1981).

\section{Perendaman dengan Immunostimulan dan Uji Papar dengan WSSV}

Penelitian ini dilakukan pada skala laboratorium dengan menggunakan stoples kaca berkapasitas $3 \mathrm{~L}$ yang masing-masing diisi $2 \mathrm{~L}$ air bersalinitas $27-28$ 
ppt yang telah disterilkan dengan kaporit dan dinetralkan dengan natrium thiosulfat. Tiap stoples diisi 30 ekor benur windu PL-20 yang sebelumnya telah diaklimatisasikan terhadap suhu dan salinitas air. Dalam penelitian ini digunakan rancangan acak lengkap (RAL) pola faktorial, masing-masing dengan tiga ulangan. Faktor A (jenis immunostimulan) meliputi: 1) LPS vibrio metode ekstraksi air-phenol panas (produksi Balai Riset Perikanan Budi Daya Air Tawar, Bogor); 2) vaksin vibrio metode suhu (produksi Balai Riset Perikanan Budidaya Air Payau, Maros); 3) vaksin vibrio metode formalin (produksi Balai Riset Perikanan Budidaya Air Payau, Maros); 4) vaksin virus WSSV metode formalin (produksi Balai Riset Perikanan Budidaya Air Payau, Maros). Sedangkan faktor B (dosis vitamin C Polyphosphat) adalah: 1) 0,00 mg/L; 2) 0,01 mg/L; 3) 0,03 mg/L; dan 4) 0,05 $\mathrm{mg} / \mathrm{L}$. Keempat jenis immunostimulan diaplikasikan dengan frekuensi 3 kali, yaitu pada hari ke-1, ke-5, dan ke-9. Sedangkan penambahan vitamin $\mathrm{C}$ ke dalam media dilakukan setiap hari hingga hari ke-8. Uji papar (infeksi buatan) dengan WSSV pada konsentrasi LC (konsentrasi virus yang mematikan $50 \%$ udang yang tidak divaksin dan tidak diberi vitamin C) dilakukan pada hari ke-12. Pengamatan kematian benur windu dilakukan 24 jam setelah uji papar.

\section{ANALISIS HASIL}

\section{Sintasan Pascalarva Udang Windu}

Sintasan pascalarva udang dianalisis ragamnya dan dilanjutkan dengan uji Beda Nyata Terkecil (Steel \& Torrie, 1981). Sebelum dianalis ragam, data sintasan pascalarva udang windu dinormalkan dengan transformasi Arcsine (Fowler \& Cohen, 1990).

\section{Tingkat Sintasan Relatif (Relative Percent Survival)}

Untuk mengetahui efikasi vaksinasi, maka dilakukan penghitungan tingkat sintasan relatif atau relative percent survival (RPS) pascalarva udang windu dengan menggunakan rumus Ellis (1988) sebagai berikut:

$\mathrm{RPS}=\left(1-\frac{\% \text { Mortalitas udang yang divaksin }}{\% \text { Mortalitas udang kontrol }}\right) \times 100 \%$

Jika nilai RPS-nya 50\% atau lebih maka vaksin tersebut efektif untuk digunakan (Ellis, 1988).

\section{HASIL DAN BAHASAN}

Penampakan udang yang terserang WSSV yang dikoleksi sebagai sumber vaksin dan sumber WSSV pada uji tantang disajikan pada Gambar 1.

Hasil analisis probit terhadap data kematian pascalarva udang windu di laboratorium menunjukkan bahwa konsentrasi WSSV yang mematikan 50\% pascalarva udang windu setelah 24 jam perendaman adalah 46,27 mL/2L air media. Konsentrasi ini selanjutnya digunakan untuk uji papar pada penelitian pengaruh penggunaan immunostimulan dan penambahan Vit. C terhadap pascalarva udang windu. $\mathrm{LC}_{50} \%$ WSSV yang didapatkan pada penelitian ini sedikit lebih tinggi dibanding LC $_{50} \%$ WSSV yang didapatkan tahun sebelumnya ( $30 \mathrm{~mL} / 2$ air media). $\mathrm{Hal}$ ini menunjukkan bahwa penyimpanan telah menurunkan tingkat virulensi WSSV terhadap pascalarva udang windu.

Penggunaan vaksin vibrio metode formalin dengan penambahan Vit. C 0,05 mg/L memberikan sintasan

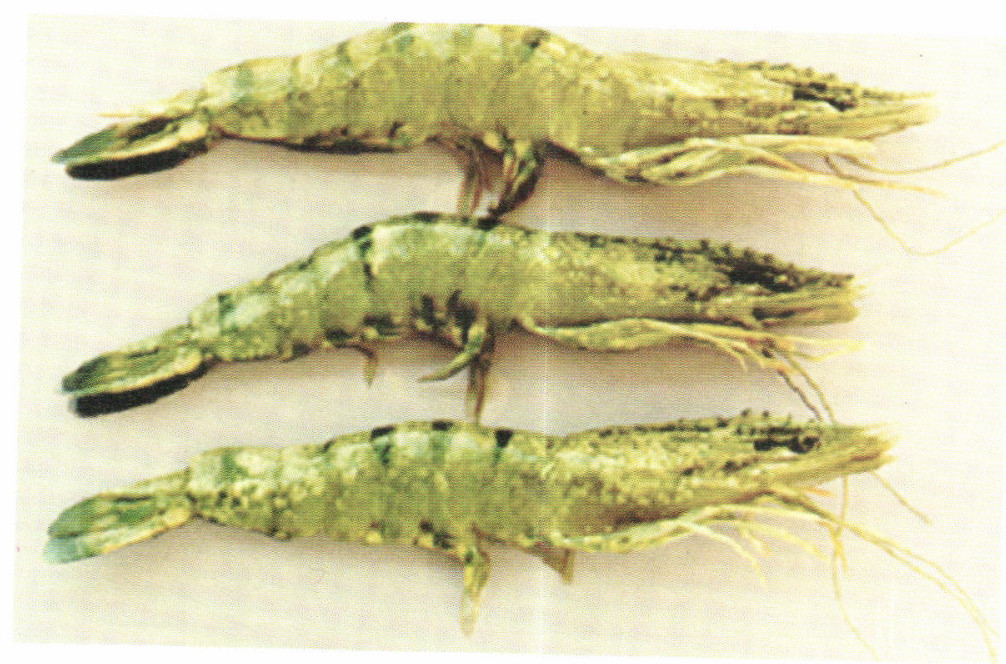

Gambar 1. Penampakan udang windu yang terserang White Spot Syndrome Virus (WSSV)

Figure 1. Tiger shrimp performance infected by White Spot Syndrome Virus (WSSV) 
pascalarva udang windu tertinggi yaitu sebesar $52,22 \%$, kemudian menyusul penggunaan vaksin WSSV dengan penambahan vitamin C $0,03 \mathrm{mg} / \mathrm{L}$ sebesar $43,33 \%$ dan terendah pada kontrol (tanpa immunostimulan) yaitu $5,55 \%$ (Tabel 1). Hasil penelitian terdahulu menunjukkan bahwa tingkat sintasan tertinggi larva udang windu yang dipapar dengan WSSV didapatkan pada pemberian LPS vibrio dengan konsentrasi $30 \mathrm{~g} / \mathrm{kg}$ pakan (Hamzah, 2001) sebesar $52,33 \%$.

Hasil analisis ragammenunjukkan bahwa terdapat perbedaan yang nyata $(P<0,05)$ antara sintasan pascalarva udang windu pada perlakuan penggunaan vaksin vibrio metode formalin + Vitamin C $0,04 \mathrm{mg} / \mathrm{L}$ dengan kontrol (tanpa immunostimulan) dan perlakuan yang menggunakan vaksin WSSV + Vitamin C 0,01 $\mathrm{mg} / \mathrm{L}$. Hal ini menunjukkan bahwa vaksin vibrio yang digunakan memberikan efek yang lebih baik terhadap terbentuknya kekebalan tubuh pada pascalarva udang windu, sehingga lebih tahan terhadap serangan WSSV. Meskipun vaksinasi hasilnya hanya baik untuk hewan bertulang belakang seperti ikan, akan tetapi vaksinasi di sini juga dapat meningkatkan pertahanan humoral (terbentuknya Ab protektif) dan pertahanan humoral pada krustase dapat dibentuk melalui antibacterial protein seperti LPS dan B-glukan (Soderhall, 1998; Kamiso, 1996). Selanjutnya dikatakan bahwa walaupun sistem kekebalan tubuh pada udang tidak spesifik, namun sistem kekebalan tersebut terbentuk jika bersentuhan dengan benda asing. Takahashi et al. (1998) melaporkan bahwa fucoidan, semacam sulfat polysakarida dari alga coklat dapat mencegah serangan WSSV pada udang.

Menurut Vargas-Albores et al. (1998), Lipopolisakarida dari bakteri dan b-glukan dari jamur dapat mengaktifkan pertahanan selular pada udang dengan meningkatkan sifat fagositosis, melanisasi, enkapsulasi, dan koagulasi pada udang, sedangkan menurut Roux et al. (2002), Lipopolisakarida dan B1,3 glucan binding protein (LGBP) memegang peranan penting dalam sistem pertahanan pada krustase dan insekta. Devaraja et al. (1998) melaporkan bahwa immunostimulasi pada udang windu dapat ditingkatkan dengan pemberian bakterisidal dari bakteri vibrio (yang dimatikan dengan pemanasan) yang dikombinasikan dengan b-glukan. Sedangkan

Tabel 1. Sintasan pascalarva udang windu (\%) setelah 24 jam perendaman dengan virus WSSV Table 1. Survival rate (\%) of tiger shrimp postlarvae after 24 hours exposed with WSSV virus

\begin{tabular}{|c|c|c|}
\hline Jenis vaksin (Kinds of vaccine) & $\begin{array}{c}\text { Dosis Vit. C (mg/L) } \\
\text { Dosage of Vit. C } \\
\text { (mg/L) }\end{array}$ & $\begin{array}{c}\text { Sintasan }(\%) \text { larva udang windu } \\
\text { Survival rate (\%) of tiger shrimp } \\
\text { larvae }\end{array}$ \\
\hline \multirow{4}{*}{$\begin{array}{l}\text { LPS vibrio metode ekstraksi air phenol panas } \\
\text { Hot water-phenol-extracted vibrio LPS }\end{array}$} & 0.00 & $38.00^{\mathrm{ab}}$ \\
\hline & 0.01 & $31.11^{\mathrm{ab}}$ \\
\hline & 0.03 & $19.98^{a b}$ \\
\hline & 0.05 & $15.55^{\mathrm{ab}}$ \\
\hline \multirow{4}{*}{$\begin{array}{l}\text { Vaksin vibrio metode pemanasan pada suhu } 100^{\circ} \mathrm{C} \\
100^{\circ} \mathrm{C} \text { heat-killed vibrio }\end{array}$} & 0.00 & $38.89^{a b}$ \\
\hline & 0.01 & $33.33^{a b}$ \\
\hline & 0.03 & $26.67^{\mathrm{ab}}$ \\
\hline & 0.05 & $36.66^{\mathrm{ab}}$ \\
\hline \multirow{4}{*}{$\begin{array}{l}\text { Vaksin vibrio metode formalin } \\
\text { Formalin-killed vibrio }\end{array}$} & 0.00 & $20.00^{a b}$ \\
\hline & 0.01 & $12.22^{a b}$ \\
\hline & 0.03 & $8.89^{b}$ \\
\hline & 0.05 & $52.22^{a}$ \\
\hline \multirow{4}{*}{$\begin{array}{l}\text { Vaksin WSSV metode formalin } \\
\text { Formalin-kiled WSSV }\end{array}$} & 0.00 & $14.44^{\mathrm{ab}}$ \\
\hline & 0.01 & $7.78^{\mathrm{b}}$ \\
\hline & 0.03 & $43.33^{a b}$ \\
\hline & 0.05 & $24.22^{a b}$ \\
\hline
\end{tabular}

Tanpa vaksinasi

$5.55^{\mathrm{b}}$

\section{Without vaccine}

-) Nilai rata-rata diikuti huruf yang sama dalam kolom yang sama, tidak menunjukkan perbedaan nyata pada taraf nyata $(P>0,05)$

-) Values in the column followed by the same superscript are not significantly different $(P>0.05)$ 
Tabel2. Tingkat Sintasan Relatif (RPS) pascalarva udang windu setelah 24 jam perlakuan Tabel 2. Relative Percent Survival (RPS) value of tiger shrimp postlarvae after 24 hours treatment

\begin{tabular}{lcc}
\hline \multicolumn{1}{c}{$\begin{array}{c}\text { Jenis vaksin } \\
\text { Kinds of vaccine }\end{array}$} & $\begin{array}{c}\text { Dosis Vit. C (mg/L) } \\
\text { Dosage of Vit. C(mg/L) }\end{array}$ & $\begin{array}{c}\text { Nilai RPS (\%) } \\
\text { RPS value (\%) }\end{array}$ \\
\hline LPS vibrio metode ekstraksi air-phenol panas & 0.00 & 26 \\
Hot water-phenol-extracted vibrio LPS & 0.01 & 27 \\
& 0.03 & 5 \\
Vaksin vibrio metode pemanasan pada suhu $100^{\circ} \mathrm{C}$ & 0.05 & 11 \\
\hline $100^{\circ}$ C heat-killed vibrio & 0.00 & 35 \\
& 0.01 & 29 \\
& 0.03 & 22 \\
Vaksin vibrio metode formalin & 0.05 & 33 \\
Formalin-killed vibrio & 0.00 & 15 \\
& 0.01 & 7 \\
& 0.03 & 4 \\
Vaksin WSSV metode formalin & 0.05 & 50 \\
Formalin-killed WSSV & 0.00 & 9 \\
& 0.01 & 2 \\
\hline
\end{tabular}

menurut Sung et al. (1994), B-glukan dapat meningkatkan aktivitas phenoloksidase pada hemosit udang. Berdasarkan hasil-hasil penelitian tersebut menunjukkan bahwa pertahanan intraseluler udang dapat dirangsang dengan meningkatkan sistem immunostimulasinya.

Hasil analisis nilai RPS larva udang windu pada semua perlakuan disajikan pada Tabel 2. Pada tabel tersebut terlihat bahwa nilai RPS tertinggi dihasilkan oleh vaksin vibrio + Vitamin $\mathrm{C} 0,05 \mathrm{mg} / \mathrm{L}$ yaitu sebesar $50 \%$ dan terendah dihasilkan oleh vaksin WSSV metode formalin $+0,01$ Vitamin $\mathrm{C} \mathrm{mg} / \mathrm{L}$. Hal ini menunjukkan bahwa jenis vaksin ini memiliki efikasi paling tinggi. Menurut Ellis (1988), vaksin dapat dikatakan efektif jika nilai RPS-nya $50 \%$ atau lebih. Beberapa hal dapat dilakukan untuk meningkatkan efikasi vaksin di antaranya adalah memberikan buster yaitu vaksinasi ulang setelah selang beberapa waktu (Kamiso, 1996). Berdasarkan hal tersebut maka dalam penelitian ini pemberian immunostimulan dilakukan sebanyak tiga kali yaitu pada hari ke-3, ke-5, dan ke9. Cara lain yang dapat dilakukan untuk meningkatkan efikasi vaksin adalah dengan penambahan Vitamin C dan Vitamin E. Hasil penelitian Balai Riset Perikanan Budidaya Air Payau (BRPBAP) sebelumnya menunjukkan, bahwa penambahan Vitamin $C$ yang terbaik adalah $0,05 \mathrm{mg} / \mathrm{L}$ setiap 4 hari

Menurut Ellis (1988), penambahanVit. C 500$1.500 \mathrm{mg}$ dan Vitamin E $40 \mathrm{iu} / 100 \mathrm{~g}$ pakan ternyata dapat meningkatkan efikasi vaksin. Dalam penelitian ini setiap jenis vaksin dikombinasi dengan penambahan Vitamin $\mathrm{C}$ dengan tingkatan konsentrasi yaitu $0,01 \mathrm{mg} / \mathrm{L} ; 0,03 \mathrm{mg} / \mathrm{L}$; dan $0,05 \mathrm{mg} / \mathrm{L}$. Namun dari hasil perhitungan RPS (Tabel 2), terlihat bahwa tidak ada korelasi antara konsentrasi Vitamin $C$ yang ditambahkan ke dalam setiap jenis immunostimulan (vaksin) dengan nilai RPS setiap jenis vaksin (sebagai salah satu indikasi dari tingkat efikasi dari satu jenis vaksin). Hal ini diduga karena konsentrasi Vitamin C yang digunakan masih terlalu rendah jika dibandingkan dengan yang ditambahkan dalam pakan 500-1.500 $\mathrm{mg} / 100 \mathrm{~g}$ pakan (Ellis, 1988). Oleh karena itu, perlu dilakukan pengkajian yang lebih jauh tentang peranan Vitamin $\mathrm{C}$ dalam meningkatkan nilai efikasi dari suatu jenis vaksin (immunostimulan) untuk lebih meningkatkan pertahanan nonspesifik pada hewan uji.

\section{KESIMPULAN}

Kombinasi vaksin vibrio metode formalin dengan penambahan Vitamin C $0,05 \mathrm{mg} / \mathrm{L}$ lebih efektif dibandingkan immunostimulan lainnya dalam meningkatkan sintasan pascalarva udang windu dan Tingkat Sintasan Relatif (RPS)

\section{DAFTAR PUSTAKA}

Albaladejo, J.D., L.M. Tapay, V.P. Migo, C.G. Alfafara, J.R. Somga, S.L. Mayo, R.C. Miranda, K. Natividal, F.O. Magbanua, T. Itami, M. Matsumura, E.C.B. Nadala, and P.C. Loh. 1998. Screening for shrimp viruses in the Philippines. In Flegel, T.W. (Ed.). Advances in 
Shrimp Biotechnology. National Center for Genetic Engineering and Biotechnology, Bangkok, p. 252253.

Brock, T.D., M.T. Madigan, J.M. Martinko, and J. Parker. 1994. Biology of Microorganism. Seventh edition. Prentice Hall International, Inc., 909 pp.

Chang, Poh-Shing, C. Hsiao-Chao, dan W. Yu-Chi. 1998. Detection of white spot syndrome assosiated baculovirus in experimentally infected wild shrimp, crab and lobster by in situ hyridiztion. Aquaculture 164: 233-242.

Devaraja, T.N., S.K. Otta, G. Shubha, I. Karunasagar, P. Tauro, and I. Karunasagar. 1998. Immunostimulantion of shrimp through oral administration of Vibrio bacteria and yeast glucan. In Flegel, T.W. (Ed.). Advances in Shrimp Biotechnology. National Center for Genetic Engineering and Biotechnology, Bangkok, p. 167-170.

Ellis, A.E. 1988. Fish Vaccination. Academic Press, San Diego, $247 \mathrm{pp}$.

Fowler, J. and L. Cohen. 1990. Practical Statistic for Field Biology. Open University Press. Milton. Keynes. Philadelphia, 227 pp.

Hamzah, A. 2001. Stimulasi Lipopolisakarida terhadap Peningkatan Kekebalan Tubuh Udang Windu (Penaeus monodon Fab.) dari Serangan White Spot Syndrome Virus (WSSV). Tesis Pascasarjana. Universitas Hasanuddin, $67 \mathrm{pp}$.

Kamiso, H.N. 1996. Metode pencegahan hama dan penyakit ikan karantina dengan penggunaan vaksin. Makalah Disampaikan pada Seminar Hama dan Penyakit Ikan Karantina tanggal 13 Desember 1996, Cipanas, Bogor, 18 pp.

Li, Q., F. Yang, J. Zhang, and Y. Chen. 2003. Proteomic analysis of protein that bands specifically to the homologous repeat regions of white spot syndrome virus. Biol. Pharm. Bull., 26: 1,517-1,522.

Maeda, M. 1999. Microbial Process in Aquaculture. National Research Institute of Aquaculture. Nansei, Mie. 516-0193, Japan, 102 pp.

Madeali, M.I., A. Tompo, dan Muliani. 1998. Diagnosis penyakit viral pada udang windu, Penaeus monodon secara histopatologis dan antibodi poliklonal dengan metode ELISA. J. Pen. Per. indonesia IV (3):11-18

Madigan, M.T., J.M. Martinko, and J. Parker. 2000. Brock: Biologi of Microorganisms. Ninth Edition. Prentice Hall. Southern Illionois University Carbondale.
Peng, S.E., C.F. Lo, S.C. Lin, L.L. Chen, Y.S. Chang, K.F. Liu, M.S. Su, and G.H. Kou. 2001. Performance of WSSV-infected and WSSV-negative Penaeus monodon postlarvae in culture ponds. Dis. Aquat. Org., 46: 165-172.

Roux, M.M., A. Pain, K.R. Klimpel, and A.K. Dhar. 2002. The Lipopolysaccharide b-1,3-Glucan Binding Protein gene is upregulated in White Spot Virus-infected shrimp (Penaeus stylirostris). Journal of Virology, 76: $7,140-7,149$

Soderhall, K. 1998. Review of Crustacean Immunity. In Flegel, T.W. (Ed.). Advances in Shrimp Biotechnology. National Center for Genetic Engineering and Biotechnology, Bangkok, p. 135-136.

Steel, R.G.D. and J.H. Torrie. 1981. Principles and Pro. cedures of Statistics. A biometrical Approach $\left(2^{\text {nd }}\right.$ edition). International Student Edition. McGraw-Hill International Book Company, $633 \mathrm{pp}$.

Supriyadi, H. 1990. Pencegahan penyakit bakterial pada usaha budidaya perikanan. Bahan Kuliah pada Pelatihan Karantina Ikan 21 Mei-4 Agustus 1990 Ciawi, Bogor, $11 \mathrm{pp}$.

Sung, H.H., G.H. Kou, and Y.L. Song. 1994. Vibriosis resistance induced by glucan treatment in tiger shrimp (Penaeus monodon). Fish Pathol., 1: 11-17.

Takahashi, Y., K. Uehara, R. Watanabe, T. Okumura, T. Yamashita, H. Omura, T. Yomo, T. Kawano, A. Kanemitsu, H. Narasaka, N. Suzuki, and T. Itami. 1998. Efficacy of oral administration of fucoidan, a sulfated polysaccharide, in controlling White Spot Syndrome in kuruma shrimp in Japan. In Flegel, T.W. (Ed.). Advances in Shrimp Biotechnology. National Center for Genetic Engineering and Biotechnology, Bangkok, p. 171-173.

Vargas-Albores, F., J. Hernandez-Lopez, T. GallasGalvan, K. Montano-Perez, F. Jimenez-Vega, and G. Yepiz-Plascencia. 1998. Activation of shrimp cellular defence functions by microbial products. In Flegel, T.W. (Ed.). Advances in Shrimp Biotechnology. National Center for Genetic Engineering and Biotechnology, Bangkok, p. 161-166.

Vaseeharan, B., R. Jayakumar, and P. Ramasamy. 2003. PCR-base detection of white spot syndrome virus in cultured and captured crustaceans in India. Lett. Appl. Microbiol., 37: 443-447.

Wolf, K. 1988. Fish Viruses and Fish Viral Diseases. Comstock Pub. Assoc, New York, 476 pp. 